\title{
Brudna \\ transcendencja. \\ Rudymenty sacrum a przemiany współczesnych ekopoetyk
}

Joanna Soćko

ORCID: 0000-0002-5297-4355

Tomas Tranströmer, którego poezja nosi znamiona surowego krajobrazu szwedzkiego wybrzeża, w wierszu 7 marca 1979 zdaje się sugerować, że przyroda jest dla niego nieoczywistym źródłem sensu. Podana w tytule data umiejscawia w czasie hipotetyczne doświadczenie, które opatrzone poetycką refleksją staje się komentarzem dotyczącym specyfiki nie-tylko-ludzkiej komunikacji:

Dość mając wszystkich, którzy przychodzą ze słowami,

ze słowami, ale nie mówiąc nic,

wyjechałem na zaśnieżoną wyspę.

Pustkowie nie zna słów.

Niezapisane stronice ciągną się na wszystkie strony!

Natrafiam na ślady sarnich kopytek w śniegu.

Mowa, choć żadnych słów ${ }^{1}$. 
Noblista przeciwstawia w tym wierszu ludzki język milczeniu przyrody, które - choć pozbawione słów będących dla człowieka najważniejszymi nośnikami znaczenia - przemawia lepiej lub też bardziej niż ludzkie komunikaty podlegające prawom swoistej inflacji czy nadprodukcji. Tym, co czyni ślady kopytek mową (språk), zdaje się odczytanie ich w kategoriach klasycznie rozumianego znaku: stają się one śladem odsyłającym do życia, które go pozostawiło. Z kolei słowa (ord) odsyłają jedynie do siebie nawzajem, bazując na słownikowych definicjach i cyrkulując w obiegach zdań włączających je w skomplikowane układy odniesień. Taka optyka sugeruje, że zużycie czy wytarcie, jakiemu podlegają wyrażenia, wiąże się z oderwaniem treści od żywego podmiotu zostawiającego znaki. I choć wiersz ten wpisuje się w romantyczny topos przyrody dającej odpoczynek od męczącego, coraz bardziej zindustrializowanego czy stechnicyzowanego świata ludzi, jest on też metaliteracką refleksją przedstawiającą naturalny krajobraz jako miejsce, w którym poszukuje się źródła sensu mogącego zasilić słabnącą moc komunikacji.

Na potencjalną siłę ekspresji kryjącą się w żywiole natury zwracała również uwagę Wisława Szymborska, która w wierszu Obmyślam świat pisała o „przeczuwanej improwizacji lasu”, „epice sów” czy „aforyzmach jeża”2. Podobnie jak Tranströmer sugerowała ona jednak - czemu dała wyraz również w Milczeniu roślin ${ }^{3}$ - że w znanej nam rzeczywistości nie ukażą się one nigdy w „jawie słów”, pozostając - tak jak śnieżne pustkowie i odciski kopyt - poza ludzką możliwością werbalizacji. Pragnienie „dostrojenia” poetyckiego języka do materii przyrody nie opuszczało jednak najbardziej rozpoznawalnych poetów końca XX wieku, do których zaliczał się również Seamus Heaney marzący m.in. o tym, by trzymane w jego dłoni pióro zagłębiało się i wynurzało na powierzchnię tak jak szpadel jego ojca i dziadka zanurzał się w ziemi, dziarsko przekopując torf. Co miałoby jednak odpowiadać w tej analogii wykopywanym przez jego przodków ziemniakom - chłodnym i twardym, nieprzeniknionym jak kamień z wiersza Wisławy Szymborskiej?4.

We wszystkich przywołanych utworach konkretne elementy przyrody stawiają językowi opór, niosąc w sobie zarazem niejasną obietnicę niedyskursywnego znaczenia, kryjącego się w twardej lub miękkiej, mokrej lub suchej materii, której specyfika nadaje sens poetyckim tropom i figuracjom. Jej niezgłębione jądro zdaje się tu stanowić transcendentną „resztę”, która, będąc zawsze poza dyskursywnym uniwersum właściwym człowiekowi, może jednak wpływać na istniejące w nim układy odniesień. Naturalnemu środowisku nadaje się tu status tego, co „zewnętrzne” wobec świata ludzi rozumianego jako językowy konstrukt. Chciałabym w tym właśnie kontekście przemyśleć w niniejszym artykule funkcjonalność kategorii transcendencji w odniesieniu do wybranej poezji XX i XXI wieku, wychodząc z założenia, że przemiany tego „transcendentnego” paradygmatu mogą rzucić światło na niektóre przynajmniej transformacje widoczne we współczesnych ekopoetykach.

\footnotetext{
${ }^{2}$ Wisława Szymborska, „Obmyślam świat”, w Wołanie do Yeti (Kraków: Wyd. Literackie, 1957), 15.

${ }^{3}$ Wisława Szymborska, „Milczenie roślin”, w Widok z ziarnkiem piasku: 102 wiersze (Poznań: Wyd. a5, 1996), 27.

${ }^{4}$ Zob. Wisława Szymborska, „Rozmowa z kamieniem”, w Sól (Warszawa: Państwowy Instytut Wydawniczy, 1962), 56-58.
} 


\section{Rekonfiguracje transcendencji}

„Transcendencja” jest terminem problematycznym, podlegającym wielu redefinicjom i rewaluacjom w długiej historii filozofii i religii. Przedstawiana przez wieki - w różnych „wariantach” - jako uprzywilejowany modus istnienia implikujący byty wieczne i doskonałe oraz użyczające światła przemijającym i ułomnym rzeczom „tego świata”, w XIX wieku została „zrzucona z piedestału" zarówno przez Georga W.F. Hegla, dla którego filozofia stała się spekulacją na temat śmierci Boga, jak i Friedricha Nietzschego, który ideę Boga utożsamił z ograniczeniem, jakie ludzie narzucili sami sobie, dorastając w końcu do tego, by ostatecznie je odrzucić. Tradycyjnie rozumiana transcendencja kurczyła się proporcjonalnie do zachodzących procesów sekularyzacyjnych ${ }^{5}$, a żywiołem nowoczesności, jak sugerował Hans Jonas, stała się bezwarunkowa immanencja, umożliwiająca zmierzenie się z problemem naszego bycia-w-świecie bez odwoływania się do cudownych ingerencji „z zewnątrz”.

Nie oznacza to jednak, że ponowoczesna humanistyka zarzuciła pytania o transcendentny modus istnienia. Redaktorzy pokonferencyjnego tomu Transcendence and Beyond. A Postmodern Inquiry z cyklu „Religion and Postmodernism” wskazali dwa główne paradygmaty, w ramach których współcześnie podejmuje się refleksję nad tą kategorią. Pierwszy z nich, kojarzony z takimi myślicielami, jak Emmanuel Lévinas, Jacques Derrida czy Jean-Luc Marion wiąże się z przekonaniem, że dotychczasowe wyobrażenia dotyczące transcendencji nie były wystarczająco transcendentne, co ma swoje źródło w nieufności wobec języka. Koncepcje nawiązujące do „całkowicie Innego”, różni, (czy czegoś tu nie brakuje?) Derridiańskiej khory, czy „Boga bez bycia” dekonstruowały więc dotychczasowe kategorie, w których ramach filozofia i teologia ujmowały zagadnienie transcendencji, postulując sposób myślenia, nazwany przez Johna Caputo i Michaela Scanlona „hipertranscendentnym”7. Drugi paradygmat, mianowany przez redaktorów tomu „posttranscendentnym”, związany jest z takimi myślicielami jak Gilles Deleuze czy Luce Irigaray i obejmuje współczesną refleksję dotyczącą rehabilitacji materializmu, przedstawiając wszelkiego rodzaju transcendencje jako wydarzające się w obrębie immanencji. Paradygmat ten scharakteryzowała obszernie Patrice Haynes, nadając mu miano „transcendencji immanentnej” - kategorii ufundowanej na przekonaniu, że „konceptualizacje materii powstające w obrębie współczesnej, kontynentalnej filozofii pociągają za sobą transwaluację transcendencji”. Ostatecznie - jak piszą Caputo i Scanlon - „słowo «transcendencja» jest określeniem relatywnym, zależącym od tego, poza co dokładnie chcemy wyjść, a lista kandydatów jest długa: podmiot, jaźń, świat zmysłowy, czy samo Bycie..."9.

Ekokrytyka, rozwijając się równolegle do strukturalizmu i teorii poststrukturalnych, od początku borykała się z problemem statusu pozatekstowej rzeczywistości. Z jednej strony cele,

\footnotetext{
${ }^{5}$ Zob Charles Taylor, A Secular Age (Cambridge (Mass.): Belknap Press of Harvard University Press, 2007), 618675.

${ }^{6}$ Hans Jonas, Mortality and Morality: A Search for the Good after Auschwitz, red. Lawrence Vogel (Evanston, Ill.: Northwestern University Press, 1996), 134.

${ }^{7}$ Michael J. Scanlon i John D. Caputo, Transcendence and Beyond. A Postmodern Inquiry, The Indiana Series in the Philosophy of Religion (Bloomington: Indiana University Press, 2007), 15.

${ }^{8}$ Patrice Haynes, Immanent Transcendence: Reconfiguring Materialism in Continental Philosophy (London: Bloomsbury, 2014), 1.

${ }^{9}$ Scanlon i Caputo, Transcendence and Beyond. A Postmodern Inquiry, 15.
} 
jakie stawiali przed sobą badacze związani z szeroko rozumianą humanistyką środowiskową, wykluczały zgodę na zredukowanie przyrody do statusu językowego konstruktu. Z drugiej strony trudno było im przy tym uniknąć prostej referencyjności czy pułapki esencjalizmu. Dlatego też, wychodząc od poetyckich intuicji i mając na uwadze dwa omówione powyżej przesunięcia współczesnych ujęć kategorii transcendencji (jak najdalej od pułapek języka, za to w stronę nowego rozumienia materii), chciałabym na potrzeby niniejszego artykułu zaproponować alternatywne spojrzenie na stosunek pomiędzy tekstowymi reprezentacjami a środowiskiem naturalnym. W najogólniejszym rozumieniu za immanentne uważam tutaj ludzkie uniwersum miar i znaków, systemów językowych i symbolicznych odniesień, które warunkuje pozyskiwanie wiedzy na temat „zewnętrznego” - a zatem znajdującego się poza tym uniwersum - świata. Perspektywa ta odpowiada w pewnej mierze koncepcji „hermetycznego humanizmu” (exclusive humanism) czy „uniwersum zbuforowanych jaźni” (our universe of buffered selves) ${ }^{10}$ Charlesa Taylora, który w swoim obszernym dziele A Secular Age starał się dowieść, że związane z sekularyzacją i rozwojem nauki procesy odczarowywania świata postępowały równolegle z przemieszczaniem źródła wszelkiej sprawczości w obręb ludzkiego umysłu i doprowadziły do postawienia granicy - buforu - pomiędzy człowiekiem a szeroko rozumianym światem.

Analogicznie, na przekór tradycyjnemu rozumieniu tego terminu, jako transcendentne postrzegam tu wszystko to, co wykracza poza owo ludzkie uniwersum znaków. Zwłaszcza rzeczywistość materialną będącą dla człowieka nieredukowalnym punktem odniesienia, który z jednej strony stawia językowi opór w postaci swojej niedyskursywnej „reszty”, z drugiej zaś determinuje istnienie immanentnego świata ludzi, będąc właściwym środowiskiem ich bytowania. Przyroda wydaje się przy tym pełnić w hierarchii tak postrzeganych „bytów transcendentnych" funkcję szczególną. Po pierwsze dlatego, że jako niestworzona przez człowieka w najpełniejszy sposób reprezentuje to, co nie-ludzkie. Po drugie zaś w stopniu najbardziej podstawowym warunkuje życie człowieka jako istoty biologicznej. Takie przedefiniowanie transcendencji odpowiada poniekąd ustaleniom poczynionym przez socjologów badających reprezentatywną grupę zadeklarowanych niewierzących osób z Danii, Szwecji i Estonii - krajów zsekularyzowanych, na których terenie znajduje się wiele miejsc naturalnych nienoszących znamion ludzkiej ingerencji. W artykule The relocation of transcendence socjologowie ci, przedstawiając wyniki swoich badań, wyrazili pogląd, że - przynajmniej w kontekście mieszkańców tych konkretnych krajów - zauważyć można wyraźne przemieszczenie źródła doświadczeń związanych $\mathrm{z}$ transcendencją ze sfery sacrum do sfery przyrody ${ }^{11}$. Proponowane przeze mnie ujęcie immanencji i transcendencji nie jest jednak tożsame ze światopoglądem kojarzonym zwyczajowo $\mathrm{z}$ anglosaskim romantyzmem czy amerykańskim transcendentalizmem, lokującym co prawda w przyrodzie specyficzne źródło sacrum, którego doświadczenie wiązało się jednak z wykroczeniem poza zmysłowy porządek rzeczy. O różnicy między tymi ujęciami przesądza, jak uważam, odmiennie definiowana immanencja.

\footnotetext{
${ }^{10}$ Zob. Charles Taylor, „The Bulwarks of Belief”, w A Secular Age (Cambridge (Mass.): Belknap Press of Harvard University Press, 2007), 25-89.

${ }^{11}$ Zob. D. Thurffell i in., „The Relocation of Transcendence: Using Schutz to Conceptualize the Nature Experiences of Secular People”, Nature and Culture 14, nr 2 (2019): 190-214, https://doi.org/10.3167/nc.2019.140205 (dostęp: 10.07.2021).
} 
Chciałabym przy tym zastrzec, że przedstawione tutaj rozróżnienie na transcendencję i immanencję nie jest $w$ żadnej mierze teoretyczną propozycją postrzegania świata. Jest raczej roboczą diagnozą - nieznacznym przeformułowaniem dualizmu, który - będąc spuścizną związaną ze specyficznym rozwojem najszerzej rozumianej kultury - coraz pilniej domagał się przekroczenia. Przeformułowanie to wydaje mi się jednak o tyle istotne, że choć rozróżnienie na immanencję i transcendencję jest tutaj czysto techniczne, to wiąże się z częściowym zachowaniem - jak mam nadzieję pokazać - atrybutów tradycyjnie przypisywanych obu częściom tej dychotomii.

\section{Oko i okno - spuścizna poezji modernistycznej}

W swoim debiutanckim tomie, który ukazał się w czasie uznawanym obecnie za początek okresu Wielkiego Przyspieszenia, Elizabeth Bishop umieściła wiersz przedstawiający zwyczajną scenę z życia wędkarza. Otwiera go chełpliwa informacja: „Złowiłam potężną rybę"12 (I caught a tremendous fish) zawierająca w sobie sugestię o hipotetycznym zwycięstwie człowieka nad przyrodą: technicznej wyższości poświadczonej zdobytym trofeum. Wyciągnięta z wody ryba przestaje być częścią natury: przekroczenie granicy tafli wody zamienia zwierzę w „eksponat”"13, który staje się przedmiotem oglądu, uwypuklając wpisaną w inicjalny wers dwuznaczność (mówi się przecież to catch an image lub to catch a glimpse, natomiast zaimek pierwszej osoby liczby pojedynczej jest homofonem rzeczownika eye - oko). Widok ryby konstruowany w kolejnych wersach nie ogranicza się do prostego opisu, przedstawiając czytelnikowi obraz wywołujący niesmak: płaty skóry zwisają gdzieniegdzie "jak wiekowa tapeta"14 ze zbrązowiałym wzorkiem, wdychające „okropny tlen” skrzela są „czerstwe i świeże od krwi”, mogą też „paskudnie skaleczyć”. Rentgenowskie oko wyobraźni osoby mówiącej podsuwa nam też wizję wnętrza ryby, „brzydkiego, białego mięsa ubitego jak pierze”, a także widok oka - to jednak tylko z zewnątrz, ryba nie odwzajemnia bowiem spojrzenia, a jej tęczówki „owinięte w wytartą cynfolię" spowijają się „grubym szkłem porysowanej galarety” ${ }^{15}$.

W końcu uwagę osoby mówiącej, przykuwa "pięć starych linek” z „piątką wielkich haczyków” wrośniętych w pysk zwierzęcia „jak ordery z ich wstążkami”"16. Kto zatem w tym pojedynku ostatecznie zdobywa medal? Jest przecież w tej „zdobyczy” coś odpychającego, coś, co nie pozwala bohaterce wiersza - podobnie jak pięciu poprzednim wędkarzom - definitywnie jej posiąść. Ta tajemnicza właściwość odkrywa przed nami inną jeszcze dwuznaczność wpisaną w inicjalny wers, który przedstawił nam ową rybę jako „potężną” - a zatem nie tylko wielką w sensie rozmiaru, ale też odznaczającą się swego rodzaju potęgą. Oryginał jest pod tym względem jeszcze mocniejszy, słowo tremendous przywołuje bowiem na myśl „bojaźń i drżenie”, w którego obliczu opisywana ryba - chociaż trzymana w garści - zaczyna się kojarzyć z nieuchwytnym Moby Dickiem - równie białym, co nieskosztowane przez człowieka mięso wypuszczonego ostatecznie

\footnotetext{
${ }^{12}$ Elizabeth Bishop, „Ryba”, w Santarém: wiersze oraz trzy małe prozy, tłum. Andrzej Sosnowski (Stronie Śląskie: Biuro Literackie, 2018), 21.

${ }^{13}$ Bishop, 22.

${ }^{14}$ Bishop, 21.

${ }^{15}$ Bishop, 22.

${ }^{16}$ Bishop.
} 
zwierzęcia. Mimo wyraźnej ingerencji człowieka w świat przyrody (o której świadczą zarówno wrośnięte w pysk haczyki, jak i „tęcza rozpostarta przez olej” wokół silnika łódki), mimo że ryba została wciągnięta „do świata ludzi” $i$ „nie walczy”, próby przeniknięcia uosobionego w niej misterium tremendum okazują się równie bezcelowe co straceńcza pogoń Ahaba z symbolicznej powieści Hermana Melville’a. Chociaż zmysłowy opis wyzwala w czytelniku doświadczenie pokrewne obcowaniu z przedstawianymi fakturami i pozwala uchwycić dramatyzm tej sceny, pozostawia nietknięte owo tajemnicze jądro uosobione w opisywanym zwierzęciu.

Elizabeth Bishop stała się jedną z bohaterek książki Scotta Knickerbockera Ecopoetics. The Language of Nature, the Nature of Language. Autor analizuje tu twórczość kilkorga amerykańskich poetów, u których wyczulenie na materię przyrody idzie w parze z „lingwistycznym sceptycyzmem”17 przejawiającym się w poetyckim artyzmie. Knickerbocker przeciwstawia wyróżniony przez siebie „organiczny formalizm” dwudziestowiecznej poezji konfesyjnej nawiązującej do amerykańskiej tradycji nature writing i kojarzonej zwyczajowo z ekologiczną troską. O ekopoetyckiej wartości wybranych przez niego przykładów przesądzać ma nie tyle temat utworów, ile podkreślenie materialności samego języka, zarówno poprzez zabiegi formalne pobudzające zmysł wzroku i słuchu, jak i przez stylistykę „przesączoną (infused) naturalnym światem” ${ }^{18}$. W ujęciu tym tropy stylistyczne - choć, zgodnie ze źródłosłowem, zwracają czy odbijają spojrzenie, przedstawiając ludziom obraz ich własnych stanów - zawdzięczają swoją symboliczną atrakcyjność doświadczeniu naturalnych materii i jako takie właśnie stanowią niezbywalny językowy dowód na istnienie „transcendentnego" świata przyrody. Tak rozumiany proces „re-materializacji języka” stanowiący „odpowiedź na nie-ludzką naturę”19 nazywa autor „zmysłową poesis” (sensuous poesis), która nie tyle odzwierciedla świat, ile - z wykorzystaniem wspomnianych narzędzi formalnych - „odtwarza (enact) doświadczenie złożoności, tajemniczości i piękna przyrody”20.

Przedstawiona przez Knickerbockera charakterystyka ekopoetyki odpowiada poniekąd strukturze poetyckiej epifanii, którą w polskim literaturoznawstwie błyskotliwie analizował Ryszard Nycz. Zwrócił on uwagę na modernistyczne przedefiniowanie kategorii „objawienia”, które z romantycznego, indywidualnego wglądu w nadzmysłowy porządek istnienia stało się pojęciem stricte świeckim, ujmującym „nie bezpośrednio widoczną”, „poszczególną”, „przygodną” czy „ucieleśnioną” rzeczywistość ${ }^{21}$. Jak pisze Nycz:

Poetyką epifanii nazywam wyprowadzony ze świadectw nowoczesnej literatury zespół przeświadczeń na temat specjalnego statusu i funkcji poetyckiego języka oraz reguł konstruowania artystycznej wypowiedzi, której ośrodkiem są właśnie owe „epifanie”, czyli zapisy intensywnych, nieciągłych, momentalnych śladów obecności niezwykłej wartości powszedniego istnienia rzeczy indywidualnych ${ }^{22}$.

\footnotetext{
${ }^{17}$ Scott Knickerbocker, Ecopoetics. The Language of Nature, the Nature of Language (Amherst: University of Massachusetts Press, 2012), 13.

${ }^{18}$ Knickerbocker, 185.

${ }^{19}$ Zob. Knickerbocker, 2.

${ }^{20}$ Knickerbocker, 13.

${ }^{21}$ Ryszard Nycz, „Poetyka epifanii a modernizm: od Norwida do Leśmiana”, Teksty Drugie 4 (1996): 21.

${ }^{22} \mathrm{Nycz}, 22$.
} 
Jednym z najistotniejszych przykładów polskiej poezji modernistycznej tego typu stała się dla Nycza twórczość Bolesława Leśmiana - najciekawszego bodaj dwudziestowiecznego polskiego „poety przyrody”, który - jak sam pisze w poemacie Łq̨ka - „słowami przez okno w świat wygląda" i dla którego - jak zauważył Michał Markowski - język jest narzędziem ujawniania świata, nie zaś instrumentem jego odwzorowania ${ }^{23}$. Leśmian nie tylko wcielił w wiersze, ale i teoretyzował zjawisko uchwycone przez Knickerbockera, podkreślając wagę sensualności słów ożywających w poetyckim rytmie, słów „zawadiacko barwnych” i „zuchwale rozpląsanych”, które przybierają „kształt rzeczywisty”24. Realność owego kształtu nie zasadza się jednak na właściwościach mimetycznych, ale na zmysłowości samej poezji ewokującej „pierwotną pieśni bez słów”25, która - jak pisze zainspirowany myślą Henriego Bergsona Leśmian - pochodzi z „nielogicznych dziedzin istnienia”, i która jest poza „więzami gramatyki i składni”, nie dając się uchwycić w logicznym zdaniu ${ }^{26}$. Ton tej pierwotnej pieśni rozbrzmiewa w ludzkiej duszy, ale urzeczywistnia się chwilowo jedynie w poetyckim rozbłysku, kiedy to „ożywia” słowa, dając znać o swojej obecności w obrębie ludzkiego, językowego uniwersum. W tym sensie zmysłowy, „re-materializowany” język poetycki staje się dla Leśmiana pomostem między immanencją (pojmowalnym rozumowo światem tylko-ludzkim) a transcendencją (nie-logicznym, pozajęzykowym życiem): „Twórczość językowa jest nierozerwalnie związana z twórczością poetycką. Jest ona doskonałym zjawiskiem nie tylko literackim, lecz i biologicznym. Jest triumfem człowieka nad sobą samym, jest przedłużeniem jego istoty w światy pozazwierzęce"27.

Taka relacja między immanencją a transcendencją może poniekąd wyjaśniać, dlaczego poeci z nurtu, który - dla uproszczenia - nazwę za Knickerbockerem „formalizmem organicznym”, nastawiali się głównie na wywołanie „efektów zmysłowych” odpowiadających doświadczeniu obcowania z materią przyrody. David Abram - amerykański ekolog i filozof - na którego powołuje się Knickerbocker, podkreślając (niczym Johann Gottfried Herder) biologiczne pochodzenie języka, w książce The Spell of the Sensuous wysuwa tezę, jakoby za wyodrębnienie świata „tylko-ludzkiego” odpowiadało przyjęcie arbitralnego systemu znaków służących do zapisywania komunikatów. To właśnie proces udoskonalania techniki pisma miał doprowadzić do wyabstrahowania ludzkiego uniwersum, które Abram postrzega jako specyficznie pojmowaną pułapkę:

Jesteśmy uwikłani w niezliczoną ilość abstrakcji, hipnotyzowani przez zastępy stworzonych przez człowieka technologii, które przedstawiają nam jedynie obraz nas samych (reflect us back to ourselves), i aż nazbyt łatwo jest nam zapomnieć o naszym biologicznym powinowactwie z nie-tylko-ludzkim (more-than-human) obszarem wrażeń i wrażliwości ${ }^{28}$.

\footnotetext{
${ }^{23}$ Michał Paweł Markowski, Polska literatura nowoczesna: Leśmian, Schulz, Witkacy (Kraków: Universitas, 2007), 105.

${ }^{24}$ Bolesław Leśmian, „Z rozmyślań o poezji”, w Szkice literackie, red. Jacek Trznadel (Warszawa: Państwowy Instytut Wydawniczy, 2011), 60.

${ }^{25}$ Bolesław Leśmian, „Przemiany rzeczywistości”, w Szkice literackie, red. Jacek Trznadel (Warszawa: Państwowy Instytut Wydawniczy, 2011), 44

${ }^{26}$ Leśmian, 45.

${ }^{27}$ Leśmian, „Z rozmyślań o poezji”, 71.

${ }^{28}$ David Abram, The Spell of the Sensuous. Perception and Language in the More-Than-Human World (New York: Random House, 1997), 22.
} 
Proces poetyckiej „re-materializacji” języka odpowiadałby w tym kontekście obrzędowemu nawiązaniu kontaktu z transcendentną, niedostępną dyskursywnie rzeczywistością. Tak mniej więcej ujmował to brytyjski artysta David Jones, który twierdził, że język figuratywny, bazując na odniesieniach do konkretnej materii, jest quasi-sakramentalnym (w katolickim znaczeniu tego słowa) przywołaniem rzeczywistości, dlatego też symbole bazujące na referencji do natury zdają się bardziej efektywne niż inny rodzaj odniesieńn ${ }^{29}$.

Jednym z bardziej interesujących poetów drugiej połowy XX wieku, poddających tę zależność twórczej refleksji, był uważny czytelnik Jonesa - Ronald Stuart Thomas, który zasłynął jako wnikliwy obserwator dzikich, surowych krajobrazów Walii i trudnych warunków życia lokalnych farmerów. Powracający w jego poezji topos szkła czy wodnej tafli, mogącej służyć zarówno jako okno, jak i lustro, odnosił się również do poetyckiego języka, którego używał - jak pisze w swoim autobiograficznym tomie The Echoes Return Slow - „jako okna w schronieniu; szkła, przez które można spojrzeć na rozmytą dżunglę, gdzie życie żeruje na sobie, zażarte, lecz nieme jak twarz wierzącego, zatrzymana [ambushed] w lustrze". A zaraz po tej konstatacji dodaje Thomas: „wycofanemu [retired] umysłowi o wiele łatwiej ululać się do snu w refleksach odbić" ${ }^{30}$. Słowo "wierzący” nie występuje w tym fragmencie przez przypadek. Jako pastor, Thomas niejednokrotnie problematyzował religijne ujęcia transcendencji, zwracając uwagę na ludzką skłonność do tworzenia sobie Boga na własne podobieństwo. Efekt odbicia - czyli reprezentowania w języku stricte ludzkiego doświadczenia - wydaje się w kontekście przywołanego fragmentu nieunikniony. Istotna jest jednak dla Thomasa owa podwójna referencyjność, która pozwala dostrzec poza niewyraźnym zarysem ludzkiej twarzy niestworzoną przez człowieka rzeczywistość odpowiadającą „właściwie” pojmowanej transcendencji. Dlatego też gdy Thomas zastanawia się nad przekształcanym przez człowieka środowiskiem i mechanizacją farmerskiej pracy, którą cenił za bliski (choć niełatwy i pozbawiony sentymentalizmu) związek z przyrodą, pyta: „Czy istnieje antykoncepcja/ dla maszyny, żebyśmy mogli cieszyć się/ zbliżeniem, nie dając się zasiedlić/ przez słownictwo?”31.

Przekonanie o zależności pomiędzy poetyckim językiem a materią przyrody widać również w formalnych poszukiwaniach Thomasa, który nawiązując do wybuchu bomby atomowej i potencjalnego zagrożenia wojną nuklearną, mianował się - niejako z konieczności - „twórcą radioaktywnych wersów"32. Deklaracja ta może mieć związek z najbardziej rozpoznawalną cechą formalną jego poetyki, którą stały się przerzutnie rozszczepiające zdania na wersy w taki sposób, by nadać ich poszczególnym częściom sens niejednokrotnie niedający się pogodzić z logicznym porządkiem zdania. Wydźwięk taki ma na przykład zakończenie wiersza The Signpost (czy tytuł jest w porządku?): „Czas/ jest główną drogą, wieczność/ ścieżką, której nie wybieramy”"33, pochodzący z tomu Frequencies, w którym Thomas często odwołuje się do obszarów pozostających

\footnotetext{
${ }^{29}$ David Jones, „Art and Sacrament”, w Epoch and Artist: Selected Writings, red. Harman Grisewood (Londyn: Faber and Faber) 2017, 174.

${ }^{30}$ Ronald Stuart Thomas, „The Echoes Return Slow”, w Collected Later Poems 1988-2000 (Tarset, Northumberland: Bloodaxe Books, 2013), 48.

${ }^{31}$ Ronald Stuart Thomas, „Counterpoint”, w Collected Later Poems 1988-2000 (Tarset, Northumberland: Bloodaxe Books, 2013), 115.

${ }^{32}$ Thomas, „The Echoes Return Slow”, 49.

${ }^{33}$ Ronald Stuart Thomas, „Frequencies”, w Collected Poems: 1945-1990 (London: Phoenix, 2004), 344.
} 
co prawda poza możliwością zmysłowego doświadczenia, jednak oddziałujących na człowieka niemogącego sobie poradzić $\mathrm{z}$ ich rozumowym przyswojeniem. Przykład ten dość dobrze obrazuje poetykę Thomasa, który - nieufny wobec językowych formuł ujmowania rzeczywistości transcendentnej - wykorzystywał nieintuicyjne, nieraz aporetyczne aspekty nauki o materii, by w poetycki sposób podkreślić apofatyczny charakter sacrum ${ }^{34}$.

\section{Poetyka antropocenu}

Początek XXI wieku jest cezurą umowną, ale ważną, jako że to właśnie 2000 rok zapoczątkował debatę wokół zjawiska, które Paul Crutzen i Eugene Stoermer nazwali antropocenem. Rozpoznanie mówiące o tym, że ingerencja człowieka w świat przyrody ma moc sprawczą porównywalną do sił geologicznych, zmusza do poważnych redefinicji w obrębie zarysowanych uprzednio relacji pomiędzy immanencją ludzkiego uniwersum znaków i transcendencją nie-ludzkiej rzeczywistości przyrody. Ujmowanie natury w kategoriach niewyczerpanego rezerwuaru nie-ludzkiego piękna, azylu umożliwiającego ucieczkę od świata ludzi czy niezgłębionej tajemnicy związanej z jej nie-ludzką proweniencją okazuje się nie do utrzymania. Kolejne obszary przyrody zostają wyeksploatowane, zredukowane na potrzeby człowieka lub zastąpione sztucznymi, wygodniejszymi tworzywami, a wyznaczana przez naturę sfera transcendencji kurczy się, rozpada na kawałki i - najogólniej rzecz ujmując - sekularyzuje w sensie odpowiadającym zredefiniowanemu znaczeniu tej kategorii.

Nie bez znaczenia jest z pewnością to, że implikowane przez koncepcję antropocenu konsekwencje modyfikowania przyrody wiążą się z zagrożeniem dla samych ludzi. Przewidywane następstwa niszczenia i przebudowywania naturalnych przestrzeni nieco paradoksalnie uświadamiają człowiekowi jego własną, nieredukowalną biologiczność i podatność na krzywdę, której skutki zdawały się uprzednio ograniczać do jakiejś „zewnętrznej”, nie-ludzkiej rzeczywistości. Nic dziwnego, że w dyskursie nauk humanistycznych zauważyć można rehabilitację tradycyjnych, tubylczych modeli ekologicznej wiedzy rozwijanych na podstawie praktyk animistycznych połączonych $z$ sakralizacją i tabuizacją poszczególnych sfer przyrody ${ }^{35}$. Zakorzenione $\mathrm{w}$ religijnych przekonaniach zakazy i rytuały ograniczające ingerencję człowieka w naturę są co prawda wciąż postrzegane przez współczesnego „człowieka Zachodu” jako „zabobonne”, ${ }^{36}$ bardziej jednak docenia się wynikającą z nich formę współbycia z przyrodą w kontekście tego rozciągniętego w czasie, gatunkowego samobójstwa, jakim jawi się obecnie niepohamowana eksploatacyjna działalność człowieka.

Implikowane przez koncepcję antropocenu redefinicje związków człowieka z przyrodą nie mogły pozostać bez wpływu na pojawiające się w XXI wieku ekopoetyki. W książce Recomposing Ecopoetics. North American Poetry of the Self-Conscious Anthropocene Lynn Keller na przykładzie nowszych wierszy takich poetów i poetek, jak Forrest Gander, Ed Roberson, Adam Dickinson

\footnotetext{
${ }^{34}$ Zob. Joanna Soćko, Poezja (meta)fizyczna: materialność w twórczości R.S. Thomasa (Warszawa: Instytut Badań Literackich PAN Wydawnictwo, 2017).

${ }^{35}$ Zob. np. Raymond Pierotti, Indigenous Knowledge, Ecology, and Evolutionary Biology (London: Routledge, 2012).

${ }^{36}$ Używam tego sformułowania oczywiście jako uproszczenia i skrótu myślowego, mając na uwadze to, że obecna rehabilitacja tzw. tubylczej wiedzy ekologicznej abstrahuje od religijnego kontekstu jej pozyskiwania i praktykowania.
} 
czy Jorie Graham przekonująco pokazuje, że nie sposób we współczesnej poezji przyrody nawiązywać do natury, nie przedstawiając zarazem tego, co robi z nią człowiek. Aby zilustrować tę tezę, autorka nawiązuje we wstępie do świetnego wiersza Evelyn Reilly Wing/Span/Screw/ Cluster(Aves) z tomu Styrofoam (2009), który w niebanalnej formie zestawia na równych zasadach hasła, obrazy czy symbole ewokujące latanie. Ten poetycki patchwork widoczny jest już w tytule, który skupia w sobie słowa o „ptasich” lub „lotnych” konotacjach z dopiskiem aves odsyłającym przede wszystkim do taksonomicznej nazwy ptaków, przywodzącym jednak na myśl również ulicę (skrót od avenue) oraz łacińskie pozdrowienie kojarzone zwyczajowo z Maryją i momentem zwiastowania. Do wszystkich tych trzech konotacji nawiązują dwa poprzedzające tekst obrazy: pierwszy przedstawia ptasie zwłoki na jezdni (jeden z ok. 51900 wyników wyszukiwarki Google dla „roadkill+bird”), drugi zaś to zdjęcie słynnej siedemnastowiecznej rzeźby Giovanniego Berniniego Ekstaza św. Teresy - zestawienie bardzo dobrze oddające „zderzenia” sacrum i profanum, którymi rozbrzmiewa cały długi poemat Reilly. Jak pisze Keller, św. Teresa reprezentuje w tym kontekście „tęsknotę przyziemności za transcendencją - skupienie na tym, co odrywa ludzką uwagę i troskę od świata, który warunkuje przetrwanie zarówno ludzi, jak i zwierząt" ${ }^{\prime 37}$. Jest to zapewne jedno z uzasadnionych odczytań tej poezji. Wydaje mi się jednak, że w wierszu Reilly relacja pomiędzy transcendencją a immanencją jest dużo bardziej złożona, a atrybuty transcendencji nie ograniczają się do wydzielonej strefy sacrum. Przeciwnie: poemat ten pokazuje raczej, że ludzka skłonność do transgresji przyczynia się do zatarcia granic pomiędzy „tu” i „tam”, co ostatecznie doprowadza do „profanacji” owej trudno dostępnej przestrzeni „poza”, czymkolwiek by ona była. Trafnie pokazuje to występujące w wierszu nawiązanie do lewitujących kosmicznych śmieci jako pozostałości po incydentach ludzkiej ekspansji ${ }^{38}$.

Również forma poematu obrazuje wykroczenie poza tradycyjne metody reprezentacji. Formatowanie tekstu w sposób przywodzący na myśl domeny internetowe (the actual.entangle/ man (sic) to aves (sick) ${ }^{39}$ ), równoważniki zdań charakterystyczne dla internetowych wpisów czy całe frazy wyjęte z „sieci” z jednej strony ilustrują, jak pisze Keller, „nielinearny model organizowania i przekazywania informacji, na którym bazujemy w obecnej erze globalnego handlu i konsumpcji”" ${ }^{\prime 0}$ z drugiej jednak przedstawiają przeniesienie językowych i symbolicznych reprezentacji, ludzkich koneksji i interakcji, w wirtualną przestrzeń „chmury” pozostającej w obrębie konotacji klasycznie kojarzonych z niebiańską transcendencją. Relokacja zredefiniowanej przeze mnie immanencji mieszczącej się obecnie w rejestrze „tego, co lata” tylko uwypukla jej problematyczny związek z rzeczywistością kolibrów, które co prawda najszybciej na świecie poruszają skrzydłami, ale w niedługiej przyszłości mogą przestać istnieć: Yet still. humming in fastest ::: 1200/ min (heartbeat) 50/sec (wingbeat) ${ }^{41}$.

Zatarcie granicy pomiędzy immanencją a transcendencją komplikuje również językowe sposoby autodefinicji zależne w dużej mierze od możliwości rozróżnienia pomiędzy „mną” a „innym” (nie-ludzkim), co w poezji polskiej widać wyraźnie w twórczości i recepcji wierszy takich poetów

\footnotetext{
${ }^{37}$ Lynn Keller, Recomposing Ecopoetics. North American Poetry of the Self-Conscious Anthropocene (Charlottesville: University of Virginia Press, 2018), 21.

${ }^{38}$ Evelyn Reilly, „Wing/Span/Screw/Cluster (Aves)”, w Styrofoam (New York: Roof Books, 2009), 28-29.

${ }^{39}$ Reilly, 28.

${ }^{40}$ Keller, Recomposing Ecopoetics, 23.

${ }^{41}$ Reilly, „Wing/Span/Screw/Cluster (Aves)”, 29.
} 
i poetek, jak Kacper Bartczak, Anna Adamowicz, Ilona Witkowska czy Monika Lubińska. W innym wierszu Evelyn Reilly (mówiącym m.in. o „wyginięciu” [extinction] niektórych aspektów języka, takich jak „uprzedmiotowienie podmiotu” [trudne do przełożenia: subjections of the subject]) odczytać można diagnozę dotyczącą wyczerpanego już modelu samookreślania: „Jaźń (Self) podąża za nicią narracji/ tylko po to, by rozbić się o szkło/ nieprzejrzystej komunikacji./ Ten wstrząs trwa dłużej niż

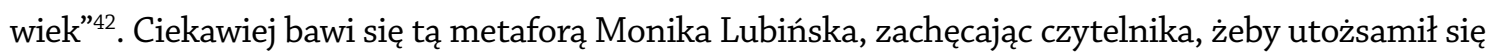
z osobą w realistycznie wyglądającym stroju syrenki, która „palcuje[sz] okna szklanki lustra”43. Ten obraz tylko pozornie odsyła do beztroskiej, dziecinnej zabawy - jest raczej niepokojącym wstępem do procesu, w którym odkrycie własnej hybrydyczności (ludzko-zwierzęcej/ kulturowo-biologicznej/ immanentno-transcendentnej) zaburza wzrokową percepcję. To dlatego, gdy „mijasz półtłuste wieprzowe/ usługi ubojowe coraz częściej/ myślisz że szyby mętnieją" ", aż w końcu „łapią cię żaby”, a "palce powieki kleją śluzem" ${ }^{5}$. I choć osoba mówiąca w jednym z wierszy tego tomu twierdzi, że „chciałaby mieć pewność siebie/ nie rzadziej niż raz na/ zawsze”"46, poetka nie pozostawia wątpliwości, że ukonstytuowanie autonomicznego podmiotu - przejrzenie się w oddalonej ode mnie materii, pokazującej całościowy obraz mej sylwetki - jest oszustwem, gdy ma się świadomość głębokiej zależności pomiędzy tym, co robimy środowisku naturalnemu i zwierzętom, a tym, kim - jako istoty biologiczne - jesteśmy: „byłam zygotą kobietą zarodkiem chłopcem/ wieprzowiną drobiem [...]/ rodziłam roboty które nic nie jadły/ a produkowały elektrośmieci”" ${ }^{\prime 7}$. A w innym miejscu pisze Lubińska: „jestem w ciąży z fasolką szparagową/ i nie wiem czy to bezpieczne dla środowiska" w charakterystyczny dla siebie sposób wytrącając czytelnika ze zwyczajowego paradygmatu myślenia o autonomii ludzkiego ciała, zaburzonego już w tytule tomu Nareszcie możemy się zjadać.

Przedstawianie życia jako żywienia (się) kwestionujące możliwość ukonstytuowania samodzielnego i niezależnego (ludzkiego) podmiotu widoczne jest również w „poczłowieczej”49 poezji Kacpra Bartczaka, w której jedynym suwerenem okazuje się właśnie sam pokarm ${ }^{50}$. Suwerenem, czyli - zgodnie z francuską etymologią tego słowa - czymś najwyższym, najważniejszym, zwierzchnim. Głównym bohaterem jednego z ostatnich tomów poetyckich Bartczaka jest bowiem „pokarm najwyższy” w oryginalny sposób nawiązujący do najważniejszego chrześcijańskiego rytu - eucharystii. Koncepcja transcendentnego Boga stającego się paradoksalnym jedzeniem mającym stanowić połączenie ludzkiego (lecz już zbawionego, a więc należącego do sfery transcendencji) ciała z materią pszennego opłatka po to, żeby zaszczepić w śmiertelnym ciele ludzi - tworzących poprzez to spożywanie organicystyczną wspólnotę ciała-Kościoła - cząstkę boskiej nieśmiertelności stanowi w tym tomie podstawę wszystkich istotnych przeistoczeń zacie-

\footnotetext{
${ }^{42}$ Evelyn Reilly, „Yet the Wor(l)d Can Still Be Very Pretty”, https://www.poetryproject.org/publications/poemstexts/yet-the-wor-l-d-can-still-be-very-pretty (dostęp: 15.04.2021). Tłumaczenie autorki.

${ }^{43}$ Monika Lubińska, „podaj liczbę”, w Nareszcie możemy się zjadać (Łódź: Stowarzyszenie Pisarzy Polskich. Oddział: Dom Literatury, 2019), 5.

${ }^{44}$ Lubińska, 6.

${ }^{45}$ Lubińska.

${ }^{46}$ Monika Lubińska, „-", w Nareszcie możemy się zjadać (Łódź: Stowarzyszenie Pisarzy Polskich. Oddział: Dom Literatury, 2019), 10.

${ }^{47}$ Lubińska.

${ }^{48}$ Monika Lubińska, „niepokalane poczęcie”, w Nareszcie możemy się zjadać (Łódź: Stowarzyszenie Pisarzy Polskich. Oddział: Dom Literatury, 2019), 15

${ }^{49}$ Zob. Wit Pietrzak, „Poezja poczłowiecza: Pokarm suweren Kacpra Bartczaka”, Er(r)go: Teoria - Literatura Kultura, nr 38, (2019): 153-163.

${ }^{50}$ Zob. Kacper Bartczak, Pokarm suweren (Stronie Śląskie: Biuro Literackie, 2017).
} 
rających wszelkie możliwe granice pomiędzy sferą transcendentną i immanentną. W procesach tych transsubstancjacji autonomię może uzyskać jedynie wiersz, który - znów: przedzierzgając chrześcijańską konwencję - jest słowem stającym się ciałem, a właściwie zarówno performatywnym symbolem, jak i materią; „wierszoorganizmem” ${ }^{1}$, który nie tyle łączy, co miesza te sfery, spajając w swoim krwiobiegu ich oddzielone od siebie mikrocząsteczki. Tak wiersz staje się nową formą wcielenia, czerpiąc jednak swoją żywotność z „ciała niechwalebnego/ bo mojego"52 splecionego $\mathrm{z}$ różnorodnych faktur materii, która - inaczej niż w chrześcijańskiej symbolice - jest mieszaniną tworzyw naturalnych i sztucznych, a jej ostateczny kształt jest wypadkową oddziaływania różnych politycznych, społecznych i gospodarczych sił pochodzących całkowicie „z tego świata”. „Zbawienne” działanie wiersza polega tu na organicznym włączeniu tej immanentnej sfery w warunkującą rzeczywistość materię, a najistotniejszym przejawem „nie-ludzkiej” przyrody jest organiczna siła wykuwająca cyborgiczne ciało wiersza przywodzące na myśl straszne muskuły tygrysa ze znanego wiersza Williama Blake’a (choć pozbawione precyzyjnej symetrii).

O ile u Leśmiana mieliśmy do czynienia z żywiołem przywodzącej na myśl Bergsonowski elan vital „pieśni bez słów”, która poprzez poezję mogła ożywić „logiczną dziedzinę istnienia”, umożliwiając człowiekowi osiągnięcie epifanicznego momentu samoświadomości; natomiast u „organicznych formalistów" takich jak Bishop czy Thomas wiersz ewokował materię rzeczywistości, by umiejscowić w jej obrębie człowieka - u „poetów antropocenu” taka dychotomia jest nie do utrzymania. W kategoriach przedefiniowanej przeze mnie immanencji i transcendencji antropocen jawi się jako odwrotność objawienia, przedstawiając ludzką ekspansyjność jako profanującą inwazję w transcendentną sferę „nie-ludzkiego”, dostępnego dotychczas jedynie na prawach właściwych rytuałom umożliwiającym ludziom udział w czymś, co ich przewyższa, a zarazem stanowi o ich istnieniu. To zaburzenie podziału na immanencję (rozumianą, przypomnę, głównie jako uniwersum miar, znaków i symboli) i analogicznie ujmowaną transcendencję uwidacznia się w poetyce, którą Anna Kałuża określiła jako „kontyngentą”53, a zatem zasadzającą się na przypadkowych zestawieniach i realizującą się w trudnych do przewidzenia aranżacjach. Połączenie wyodrębnionych przeze mnie sfer, jakkolwiek konieczne, obywa się za cenę logiczności immanentnego porządku języka, co uwidacznia się w licznych anakolutach, rozpadzie syntaktycznych form i niejednoznaczności przedstawień. Poezja takich twórców, jak Reilly, Lubińska czy Bartczak pokazuje też wyraźnie, że nie sposób już „złapać dystans”, umiejscowić się w takim punkcie widzenia, który umożliwiałby ukazanie świata czy siebie w szerszej perspektywie. Zarówno własne hybrydyczne ciało, jak i świat jawią się tutaj w sposób analogiczny do „hiperobiektów” Timothy’ego Mortona, które dotykają i „lepią się”, ale których nie możemy dostrzec w całości ${ }^{54}$. Jednak szczątki religijnej mentalności - w postaci przetworzonych fraz i profanujących odniesień - sugerują próby rekonstytucji jakiegokolwiek punktu odniesienia, pokazując, jak wysoka jest stawka tych formalnych - i z całą pewnością pozbawionych złudzeń - poszukiwań.

\footnotetext{
${ }^{51}$ Zob. Jakub Skurtys, „Pieśń kopalin i tworzyw sztucznych (wokół Wierszy organicznych Kacpra Bartczaka)”, w Ekokrytyka, red. Krzysztof Wojciechowski (Poznań: Wydawnictwo Wojewódzkiej Biblioteki Publicznej i Centrum Animacji Kultury, 2018), 33.

${ }^{52}$ Kacper Bartczak, „Konsubstancje”, w Pokarm suweren (Stronie Śląskie: Biuro Literackie, 2017), 5.

${ }^{53}$ Zob. Anna Kałuża, „Szacunki ryzyka”, https://www.dwutygodnik.com/artykul/8549-szacunki-ryzyka.html (dostęp: 15.04.2021).

${ }^{54}$ Zob. Timothy Morton, „Lepkość”, tłum. Anna Barcz, Teksty Drugie, nr 2 (2018): 284-295.
} 


\section{Bibliografia}

Abram, David. The Spell of the Sensuous. Perception and Language in the More-ThanHuman World. New York: Random House, 1997.

Bartczak, Kacper. Pokarm suweren. Stronie Śląskie: Biuro Literackie, 2017.

Bishop, Elizabeth. „Ryba”. W Santarém: wiersze oraz trzy małe prozy. Przetłumaczone przez Andrzej Sosnowski, 21-23. Stronie Śląskie: Biuro Literackie, 2018.

Haynes, Patrice. Immanent Transcendence: Reconfiguring Materialism in Continental Philosophy. London: Bloomsbury, 2014.

Jonas, Hans. Mortality and Morality: A Search for the Good after Auschwitz. Zredagowane przez Lawrence Vogel. Evanston, Ill.: Northwestern University Press, 1996.

Jones, David. „Art and Sacrament”. W Epoch and Artist: Selected Writings. Zredagowane przez Harman Grisewood, Londyn: Faber and Faber, 2017.

Kałuża, Anna. „Szacunki ryzyka”. https://www. dwutygodnik.com/artykul/8549-szacunkiryzyka.html (dostęp: 15.04.2021).

Keller, Lynn. Recomposing Ecopoetics. North American Poetry of the Self-Conscious Anthropocene. Charlottesville: University of Virginia Press, 2018.

Knickerbocker, Scott. Ecopoetics. The Language of Nature, the Nature of Language. Amherst: University of Massachusetts Press, 2012.

Leśmian, Bolesław. „Przemiany rzeczywistości”. W Szkice literackie. Zredagowane przez Jacek Trznadel. Warszawa: Państwowy Instytut Wydawniczy, 2011.

\section{_——_. „Z rozmyślań o poezji”. W Szkice} literackie. Zredagowane przez Jacek Trznadel. Warszawa: Państwowy Instytut Wydawniczy, 2011.

Lubińska, Monika. „-”. W Nareszcie możemy się zjadać. Łódź: Stowarzyszenie Pisarzy Polskich. Oddział: Dom Literatury, 2019.

\footnotetext{
_——. „niepokalane poczęcie”. W Nareszcie możemy się zjadać. Łódź: Stowarzyszenie Pisarzy Polskich. Oddział: Dom Literatury, 2019.
}

\section{——— . „podaj liczbę”. W Nareszcie możemy się zjadać. Łódź: Stowarzyszenie Pisarzy Polskich. Oddział: Dom Literatury, 2019. \\ Markowski, Michał Paweł. Polska literatura nowoczesna: Leśmian, Schulz, Witkacy. Kraków: Universitas, 2007. \\ Morton, Timothy. „Lepkość”. Przetłumaczone przez Anna Barcz. Teksty Drugie, nr 2 (2018): 284-295.}

Nycz, Ryszard. „Poetyka epifanii a modernizm: od Norwida do Leśmiana". Teksty Drugie, nr 4 (1996): 20-38.

Pierotti, Raymond. Indigenous Knowledge, Ecology, and Evolutionary Biology. London: Routledge, 2012.

Pietrzak, Wit. „Poezja poczłowiecza: Pokarm suweren Kacpra Bartczaka”. Er(r)go: Teoria Literatura - Kultura, nr 38 (2019): 153-163.

Reilly, Evelyn. „Wing/Span/Screw/Cluster (Aves)". W Styrofoam. New York: Roof Books, 2009.

- - „Yet the Wor(l)d Can Still Be Very Pretty”. https://www.poetryproject.org/ publications/poems-texts/yet-the-wor-l-dcan-still-be-very-pretty (dostęp: 15.04.2021).

Scanlon, Michael J., John D. Caputo. Transcendence and Beyond: A Postmodern Inquiry. The Indiana Series in the Philosophy of Religion. Bloomington: Indiana University Press, 2007.

Skurtys, Jakub. „Pieśń kopalin i tworzyw sztucznych (wokół Wierszy organicznych Kacpra Bartczaka)". W Ekokrytyka.

Zredagowane przez Krzysztof Wojciechowski. Poznań: Wydawnictwo Wojewódzkiej Biblioteki Publicznej i Centrum Animacji Kultury, 2018.

Soćko, Joanna. Poezja (meta)fizyczna: materialność w twórczości R.S. Thomasa. Warszawa: Instytut Badań Literackich PAN Wydawnictwo, 2017.

Szymborska, Wisława. „Milczenie roślin”. W Widok z ziarnkiem piasku: 102 wiersze, 27. Poznań: Wyd. a5, 1996. „Obmyślam świat”. W Wołanie do Yeti, 15. Kraków: Wyd. Literackie, 1957. 
-_—. „Rozmowa z kamieniem”. W Sól, 56-58. Warszawa: Państwowy Instytut Wydawniczy, 1962.

Taylor, Charles. A Secular Age. Cambridge (Mass.): Belknap Press of Harvard University Press, 2007.

- - _. „The Bulwarks of Belief”. W A Secular Age, 25-89. Cambridge (Mass.): Belknap Press of Harvard University Press, 2007.

Thomas, Ronald Stuart. „Counterpoint”. W Collected Later Poems 1988-2000. Tarset, Northumberland: Bloodaxe Books, 2013.

. „Frequencies”. W Collected Poems: 1945 1990. London: Phoenix, 2004.

- . "The Echoes Return Slow”. W Collected Later Poems 1988-2000. Tarset, Northumberland: Bloodaxe Books, 2013.

Thurfjell, D., C. Rubow, A. Remmel, i H. Ohlsson. „The Relocation of Transcendence: Using Schutz to Conceptualize the Nature Experiences of Secular People". Nature and Culture 14, nr 2 (2019): 190-214. https:// doi.org/10.3167/nc.2019.140205 (dostęp: 10.07.2021).

Tranströmer, Tomas. „7 marca 1797”. Gazeta Wyborcza, 7 października 2011. 


\title{
SŁOWA KLUCZOWE:
}

\section{ekokrytyka}

\section{M M A N E N C J A}

\begin{abstract}
AbstrakT:
Wychodząc od lektury kilku - pochodzących z końca XX w. - wierszy odnoszących się do przyrody, autorka redefiniuje tradycyjnie rozumianą transcendencję i immanencję, osadzając te kategorie w kontekście studiów postsekularnych i szeroko rozumianego nowego materializmu. Główną tezę artykułu stanowi bowiem przekonanie, że przedstawione przeformułowanie tych kategorii pozwala w ciekawy sposób przedstawić dynamikę zmian ekopoetyk charakterystycznych dla XX i XXI wieku. Omawiając wybrane przykłady poezji twórców odznaczających się wyjątkową świadomością nieprzejrzystości języka, autorka zwraca uwagę na istotną cezurę, jaką okazała się debata wokół pojęcia antropocenu i omawia obecne tendencje poetyckie, uwzględniające implikowany przez to pojęcie światopogląd.
\end{abstract}




\section{TRANSCENDENCJA}

antropocen

\section{postsekularyzm}

\section{NOTA O AUTORCE:}

Joanna Soćko - doktor, adiunkt w Instytucie Literaturoznawstwa na Wydziale Humanistycznym Uniwersytetu Śląskiego. Badaczka tekstów literackich umożliwiających lepsze rozpoznanie pogranicza współczesnych teorii ekokrytycznych i postsekularnych, fascynatka storytellingu i antropologii narracji. Autorka książki Poezja (meta)fizyczna. Materialność w twórczości R.S. Thomasa (2017, Wydawnictwo IBL), artykułów naukowych i subiektywnego przewodnika slow travel po Katowicach i okolicach. 